\title{
OPERAÇÕES MIDIÁTICAS E PROCESSO PENAL: O RESPEITO AOS DIREITOS FUNDAMENTAIS COMO FATOR LEGITIMADOR DA DECISÃO JUDICIAL NA ESFERA PENAL
}

\section{MEDIA OPERATIONS AND CRIMINAL PROCEDURE: RESPECT FOR FUNDAMENTAL RIGHTS AS A LEGITIMIZING FACTOR OF JUDICIAL DECISION IN CRIMINAL CASES}

\author{
Carlos Eduardo Koller ${ }^{1}$ \\ Igor Fernando Ruthes ${ }^{2}$
}

\section{RESUMO}

Partindo-se da premissa que as partes no processo penal tem o direito de serem informadas, bem como participar em condições de paridade, ao juiz cabe tutelar de forma intensa o princípio do contraditório previsto pela Constituição de 1988. Assumindo, portanto, o processo penal um viés mais democrático tem-se a necessidade de alterar a dogmática a fim de garantir eficácia aos direitos fundamentais, especialmente porque o ambiente no qual se formaram as principais normas de direito e processo penal foi na década de 1940.

Palavras-chave: Direitos fundamentais, Operações midiáticas, Processo penal, Decisões judiciais

\begin{abstract}
Starting from the premise that the parties in criminal proceedings has the right to be informed and participate in equal conditions, the judge fit tutelary intensely the adversarial principle laid down by the Constitution of 1988. Assuming, therefore, the criminal proceedings a more democratic bias has been the need to change the dogmatic to ensure effectiveness of fundamental rights, especially since the environment in which they formed the main rules of criminal law and procedure was in the 1940s.
\end{abstract}

Keywords: Fundamental rights, Media operations, Criminal proceedings, Judicial decisions

\footnotetext{
${ }^{1}$ Doutorando em Direito Econômico e Desenvolvimento pela Pontifícia Universidade Católica do Paraná - PUC/PR, Paraná, (Brasil). Professor Pesquisador pelo Centro Universitário Autônomo do Brasil - UNIBRASIL, Paraná, (Brasil). E-mail: carloseduardokoller@gmail.com

2 Mestrando em Direitos Fundamentais e Democracia pelo Centro Universitário Autônomo do Brasil UNIBRASIL, Paraná, (Brasil). Professor pelo Centro Universitário Internacional - UNINTER e pelo Centro Universitário Autônomo do Brasil - UNIBRASIL, Paraná, (Brasil). E-mail: ifruthes@gmail.com
} 


\section{INTRODUÇÃO}

As recentes operações realizadas pela Polícia Judiciária no Brasil têm ganhado um espaço de revelo nas mídias nacional e internacional. Fomentando a criação de figuras heroicas e maquiavélicas são inseridos no imaginário popular ideias de uma suposta disputa entre o bem e mal. Isso vem introduzindo na população um movimento por justiça a qualquer custo.

Algo se repete contemporaneamente. A História já comprovou que muitas vezes o clamor popular que avoca a exigência de ações pautadas em execuções sumárias ou linchamentos públicos não tem o condão de trazer soluções para os problemas sociais, a não ser intensificá-los. E tangente à esta intensificação estão o aumento da miséria, a diminuição da cultura popular, o baixo desenvolvimento econômico, bem como os recentes escândalos de corrupção envolvendo agentes públicos e grandes empresários no Brasil.

É neste momento que se apresenta o processo penal como um instrumento constitucional de garantia dos direitos fundamentais dos acusados. Este artigo tem como principal objetivo averiguar qual o papel que o Direito Processual Penal deve desempenhar no que tange à segurança jurídica e aos direitos fundamentais. Portanto, temas como aumento da miséria, diminuição da cultura popular, baixo desenvolvimento econômico e a especificação dos principais escândalos em corrupção são apenas exemplos da proposta científica aqui traçada. Quer se dizer, não serão objeto de investigação a partir desta pesquisa.

Buscando de forma sistemática qual a natureza jurídica do processo penal, também cotejando-a com os valores fundamentais das sociedades atuais, em termos de civilização, os direitos fundamentais surgem categoricamente como protagonistas destas ações, devendo subsidiá-las em qualquer circunstância.

Teoricamente divido em estanques teóricos, o presente artigo abordará a questão do processo penal como relação jurídica, como situação jurídica, como procedimento em contraditório para, por fim, atestar a sua instrumentalidade constitucional. 


\section{DO PROCESSO PENAL COMO RELAÇÃO JURÍDICA}

A ciência processual penal apresenta grande abrangência e se volta ao estudo de variadas temáticas. Contemporaneamente três vetores a compõe: a jurisdição, a ação e o processo. O raciocínio aqui desenvolvido partirá do processo com a finalidade de demonstrar o efeito que as garantias constitucionais proporcionam ao imputado, especialmente limitando o poder punitivo estatal.

Aperfeiçoando o recorte metodológico deste ensaio tem-se a necessidade de investigação da natureza jurídica do processo. Daí que a abordagem das teorias da relação e situação jurídicas importam. Ponderar-se-á, também, a importância que este breve apanhado representará para, em seguida, comprovar a separação das premissas teóricas da ciência processual penal daquelas comuns ao direito privado. Seus efeitos no comportamento esperado dos sujeitos processuais, bem como na produção de provas, nas nulidades e outros bastantes aspectos apenas confirmam que a natureza jurídica neste ramo apresenta-se singular, merecendo tratamento igualmente particular. ${ }^{3}$

Indaga-se, portanto, quais seriam os impactos frente a segurança jurídica da adoção destas considerações?

A teoria da relação jurídica, embora não seja a primeira formulada acerca da natureza do processo, ganha especial relevo, pois é a partir da polêmica MUTHER/WINDSCHEID a respeito do direito de ação que $B U L L O W$ pode finalmente traçar os contornos de uma ciência processual autônoma em relação ao direito material. (CAMARGO, apud. COUTINHO, 2001, p. 137-142).

Foi aí que Oskar von BULLOW (2015, p. 1-2) considerou que o processo civil desenvolvia-se por meio de uma relação autônoma entre as partes e os funcionários públicos. As partes comprometiam-se em prestar todo o auxílio necessário para que se chegue a uma decisão e de se submeter a vontade estatal manifestada por meio da sentença.

\footnotetext{
${ }^{3}$ Cumpre ressaltar que existem outras teorias que precederam esta como a teoria do contrato e a do quase- contrato, contudo estas partem de uma premissa errada ao enquadrar os institutos processuais em categorias do direito privado (CINTRA; GRINOVER; DINAMARCO; 2005, p. 287-289).
} 
Mantinha a posição este jurista germânico que até aquele momento o processo compreendia-se como sendo uma relação jurídica de direito privado, todavia acusava a existência de um risco nessa posição filosófica, advertindo que tal visão não poderia ser sustentada.

A relação processual se dava com a participação de funcionários públicos. Ainda, ponderava também que era por meio desta que o Estado dava concretude a sua função jurisdicional, razão pela qual estava a se tratar de um instituto de direito público e não de um contrato privado ou algo semelhante. (BULLOW, 2015, p. 2).

Segundo esta teoria, para que o Estado-juiz exteriorizasse sua decisão no litígio ${ }^{4}$ era necessário que se formassem algumas relações independentes daquelas do direito material. A rigor, de forma exemplificada, ter-se-ia que verificar se o juízo tornara-se competente, se as partes eram legítimas e estariam devidamente representadas. Mais, se haveria a citação válida e o adequado pagamento de custas, dentre outros tantos requisitos. Portanto, nascia uma relação jurídica diversa da material e a sua regularidade precisava ser objeto de análise anterior à decisão do mérito da causa. Em síntese, $B U L L O W(2015$, p. 7) evidenciou a existência de pressupostos processuais.

Cumpre nesse momento asseverar que para fins processuais entende-se como relação o vinculo existente entre os participantes do processo. Dessa forma, surge entre os sujeitos processuais poderes e deveres recíprocos. ${ }^{5}$ Ademais, essa teoria teve de enfrentar um problema crucial, afinando-se na delimitação de que sujeito fará parte de dita relação processual. (COUTURE, 1958, p. 132).

É de se notar que apesar de BULLOW ter desenvolvido de forma robusta os estudos acerca do processo como relação jurídica, houve certa divergência doutrinária acerca de quem estaria envolvido nesta relação.

Como exemplo, KOHLER entendia que a relação era linear havendo apenas faculdades e deveres entre as partes. O Estado-juiz era expurgado da relação processual, sendo impossível definir qual a sua exata função. (MARQUES, in COUTINHO, 2001, p. 176-178).

HELLWIG, por seu turno, ensinava que a relação jurídica era angular, representada pela ausência de núcleo de direitos e deveres entre as partes. Ao contrário da vertente acima 
assinalada, as partes apenas se relacionavam com o Estado-juiz. (MARQUES, in COUTINHO, 2001, p. 176-178).

Por fim, WACH sustentava a teoria triangular da relação jurídica processual, na qual tanto as partes, quanto o Estado-juiz possuem mutuas relações entre si. E esta é a teoria predominantemente aceita hodiernamente. (MARQUES, in COUTINHO, 2001, p. 176-178).

As partes agem exercendo as faculdades e poderes que lhes são dadas pela lei com o fim de se resolver um conflito de interesses. O mesmo não ocorre no processo penal, tampouco no caso penal, pois o conflito de interesses não é característico da Jurisdição Penal.

Durante o tramite processual, as partes e o juiz desenvolvem vários atos de forma conjunta ou isolada. Estes atos visam a apenas um fim, qual seja, a prolação de uma sentença capaz de atrair os efeitos da coisa julgada. Conclui-se que a relação jurídica processual é a soma de várias relações complexas que pela singularidade de desígnios lhe dão o caráter de unidade.

Verticalizando o estudo do tema e debruçando-se sobre a análise da relação jurídica, em tese, existente no processo penal, deve-se afirmar que se está diante de uma relação sui generis. Isto se dá pelo fato de se exercer as faculdades e as obrigações visando à aplicação do poder punitivo estatal. (MANSINI, 1951, p. 112-113).

MANSINI (1951, p. 113-114) ao tratar do processo penal italiano afirma que a relação jurídica processual é permeada por valores constitucionais. O imputado não é mais um objeto de prova, ao contrário, é um sujeito portador de direitos subjetivos que são exercidos em juízo. Assevera ainda que a discricionariedade é deveras reduzida no momento da condução do processo e da prolação da sentença, e que quando esta é utilizada, na maioria das vezes, está em favor da liberdade.

Outro ponto defendido pelo processualista italiano é o de que apesar da relação jurídica processual penal ser formada por vários sujeitos principais e acessórios existiria nela apenas uma parte: o imputado.

\footnotetext{
${ }^{4}$ Vale lembrar que o conceito de litígio não se aplica ao processo penal. A lide entendida como uma pretensão qualificada pela resistência é comum no processo civil. Ao contrário, aqui o que está a se resolver é o caso penal, que consiste numa situação de dúvida acerca da aplicação de uma norma penal em uma situação concreta.
} 
${ }^{5}$ Conteúdo material da relação jurídica processual.

Justifica sua assertiva afirmando que o Ministério Público é órgão que pertence ao Estado que não traz suas pretensões ao processo penal, mas que efetiva a vontade da lei. ${ }^{6}$ Torna-se uma "parte imparcial". Dá como exemplo para fundamentar sua posição o convencimento, por parte do agente ministerial, da inocência do imputado. Nesse caso poderá o órgão de acusação empreender esforços conjuntos com a defesa para postular uma sentença absolutória. (MANSINI, 1951, p. 116-117).

Merece destaque que além da relação jurídica processual penal estar pautada no conteúdo material - direitos e deveres entre os sujeitos processuais - é também revestida por conteúdo formal, ou seja, pelas formas que devem ser observadas para que as faculdades sejam exercidas. (MANSINI, 1951, p. 115).

A teoria em apreço influenciou a doutrina brasileira. Um exemplo de sua adoção pode ser encontrado na obra de José Frederico MARQUES, na qual o processo penal tem a natureza de uma relação jurídica, pois os sujeitos processuais são ligados entre si com deveres, direitos, faculdades e obrigações recíprocas. (MARQUES, 1948, p. 16-9).

Aprofunda seu raciocínio dizendo que ao juiz é dada a obrigação de se manifestar sobre a lide (sic) que lhe é apresentada. Já às partes é facultado o pedido da produção de provas ao magistrado. Nesse sentido evidenciaria a relação processual que envolve as partes. (MARQUES, 1948, p. 16-19).

Em sentido similar Helio TORNAGHI (1967, p. 38-29) ensina que o processo penal é um conjunto de fatos processuais (morte da vítima), atos (busca e apreensão) e negócios jurídicos (perdão) que caminham para a prolação de uma sentença por meio de uma relação jurídica com direitos, deveres e faculdades.

\footnotetext{
${ }^{6}$ A fim de contextualizar de forma crítica o presente trabalho aponta-se a recente Operação Lava Jato, capitaneada pelo Juiz Sergio Moro no município de Curitiba. Não raras são as vezes nas quais o Ministério Público Federal se manifesta em rede nacional a fim de apresentar os argumentos da denúncia. Pois bem, se estabelecermos um paralelo com o direito privado, não seria surpreendente que este mesmo órgão posicionasse seus argumentos em um procedimento de ação civil pública qualquer. Ou seja, talvez de forma equivocada o sentimento de parte ainda pertença no processo penal, por alguma razão, àquele órgão que deveria ser imparcial e o mesmo não aconteça também na mesma intensidade no direito privado, pois ausente o fenômeno midiático desta mesma ação.
} 
A teoria em estudo traz grandes avanços para a ciência processual penal. O primeiro deles é a declaração de forma inconteste da separação entre o direito processual e o direito material, ou seja, existem duas relações jurídicas e uma é independente da outra. (LOPES JR., 2012, p. 97-101).

A segunda é a possibilidade da formação de um processo de partes que possuem reciprocamente direitos e deveres entre si. Tal premissa traz como consequência lógica a valoração do réu como pessoa detentora de direitos e deveres perante o Estado-juiz. Portanto o imputado não é mais um mero objeto de prova. (LOPES JR., 2012, p. 97-101).

Corolário das premissas acima citadas é a divisão do ônus da prova. Veja-se que ao traçar os pressupostos processuais, BULLOW leciona que existem pressupostos constitutivos, impeditivos e extintivos do processo. Nessa quadra cabe a cada parte interessada em seu reconhecimento demonstrá-los. (BULLOW, 2015, p. 9).

Por fim quando BULLOW trata dos pressupostos processuais também semeia uma teoria das nulidades processuais. $\mathrm{O}$ desrespeito aos pressupostos do processo engendrará ou a extinção prematura do feito ou a nulidade processual (LOPES JR., 2012, p. 97-101). Algo de bastante novo nasce dessas considerações e singulariza o processo penal como um todo, apartando-o do procedimento em direito privado e não mais compatibilizando-se com uma teoria geral.

Nada obstante os incontestes e robustos avanços acima descritos, a teoria da relação jurídica não é a mais apropriada para explicar a natureza jurídica do processo penal (LOPES JR., 2012, p. 97-101). Breves críticas serão adotadas neste momento em sentido oposto àquela teoria defendida.

O primeiro óbice reside no fato de que seus seguidores sequer conseguem estabelecer quem está presente na relação jurídica.

Consectário lógico desta afirmação é que não se consegue estabelecer quais são os deveres que cada sujeito tem em relação aos demais, ou seja, há um óbice de natureza subjetiva e objetiva. (GOLDSCHMIDT, 1956, p. 8). 
Na aplicação no processo penal da crítica apresentada adquire ainda maior relevo, pois inexiste qualquer elemento de conexão entre acusador e acusado. Veja-se que sequer existe uma relação material de fundo que os una. O que existe é uma situação de dúvida sobre a aplicação ou não da lei penal em um caso concreto.

Ainda no que atina ao caso penal, ao juiz é dado administrar a justiça, ou seja, ele age em decorrência da lei e de seus deveres funcionais. Logo, inexiste qualquer obrigação das partes em colaborar para a resolução da situação apresentada. As partes atuam com o fito de buscar a melhor resposta possível que atendam seus anseios. Dessa maneira não há nada que as una com conteúdo de relação jurídica. O único ponto de convergência entre elas é a submissão ao Estado-juiz e a sua decisão prolatada na sentença. (COUTURE, 1958, p. 138).

COUTURE (1958, p. 138), todavia, afirma que a teoria das relações jurídicas é a mais adotada nos atuais sistemas processuais. Dessa forma há de se buscar o porquê deste fato. Como se sabe a adesão dos espíritos a uma tese deve-se aos argumentos utilizados, as premissas e principalmente à adequação ao auditório. Oskar von BULLOW ao sustentar sua ideia de um processo fundamentado em uma relação jurídica utilizou como ponto de partida valores já aceitos pela comunidade jurídica de seu tempo. (MARQUES, 2001, p. 175-182).

Para os juristas os conceitos de direitos e deveres são deveras familiares. Ademais, trabalhar com a ideia de que ao Estado-juiz cabe solucionar uma situação de "pendência" entre as partes e que estas devem se comportar de acordo com determinadas regras possui uma alta probabilidade de adesão pelo auditório em tela. (COUTURE, 1958, p. 138).

Outro fator que auxiliou no sucesso da empreitada de $B U L L O W$ foi a estruturação de sua linha de argumentação. Para dar sustentabilidade aos seus ensinamentos o processualista germânico utiliza de argumentos pragmáticos. Veja-se, por exemplo, a afirmação de que o processo é uma relação entre pessoas, que são sujeitos de direitos e deveres, e que, portanto, o processo por ser uma relação entre sujeitos de direito deve ter como conteúdo direitos e deveres processuais. (COUTURE, 1958, p. 138).

É de se ressaltar a destreza com que BULLOW utilizou dos recursos de retórica para convencer seu auditório sobre suas afirmações. Ademais quando se utilizam argumentos pragmáticos o ônus argumentativo é integralmente transferido para quem os contesta e é o que houve com a teoria em apreço. (COUTURE, 1958, p. 138). 
Contudo, deve-se dizer que esta teoria não será a eleita neste ensaio, eis que não se coaduna com os objetivos aqui perseguidos. Razão pela qual no próximo item será abordada a teoria das situações jurídicas.

\section{DO PROCESSO PENAL COMO SITUAÇÃO JURÍDICA}

Conforme leciona Érica de Oliveira HARTAMANN a teoria do processo como situação jurídica teve como seu grande responsável James GOLDSHMIDT que escreveu vários artigos sobre o tema, consolidando sua tese em 1925. (HARTMANN, 2010, p. 330).

Dadas as falhas acima apontadas, a teoria da relação jurídica foi superada com o advento da teoria da situação jurídica. Segundo esta vertente o processo é o direito em sua forma dinâmica, ou seja, o direito em movimento. (GOLDSMITH, 1956, p. 8).

Para desconstruir a doutrina da relação jurídica o autor alemão começa por afirmar a inexistência de pressupostos processuais. $\mathrm{Na}$ verdade, estes seriam condições para a apreciação da matéria de fundo. (GOLDSMITH, 1956, p. 8).

Em situações normais existe a certeza do direito, as relações sociais, em regra, se concretizam sem nenhuma intervenção estatal (processo) na esfera cível. Já na esfera penal as normas proibitivas estão a ser respeitadas independentemente da intervenção estatal. ${ }^{7}$

Quando há a violação da norma penal ${ }^{8}$ imediatamente a estrutura estatal, por meio da ação - que provoca a Jurisdição - é colocada em movimento. Um exemplo a ser dado é o dispositivo no código penal que tipifica a lesão corporal e, para o caso de seu desrespeito estabelece uma pena em abstrato. Uma vez que seja cometido o crime em comento o Estado colocará, por vias do processo penal, o direito material em movimento para fins de verificar a procedência ou não da aplicação da lei penal no caso concreto.

\footnotetext{
${ }^{7}$ Veja-se como exemplo dada relação contratual na qual o pagamento do valor sobre o bem e a tradição da coisa aperfeiçoa a relação jurídica entre as partes. A jurisdição somente será provocada nos casos em que direitos e deveres não forem observados pelas partes. Está-se, assim, frente a situações anormais.

8 A lei penal é formada por um preceito que proíbe o cometimento da ação humana tipificada e outro preceito secundário que estabelece a sanção para a inobservância do preceito primário. Dessa forma o processo penal é condição essencial para que se aplique a sanção. Será objeto de discussão na próxima seção quais são os contornos constitucionais do processo penal.
} 
Outro aspecto que deve aqui ser evidenciado é que a unidade do processo não se perfaz pelo fato de ser uma relação jurídica. Como é sabido um processo é composto por vários atos concatenados entre si. Contudo, em virtude de sua quantidade e conteúdos diversos não podem ser entendidos como uma relação jurídica. (LOPES JR., 2012, p. 105106).

Tais atos são várias situações que geram ônus, ${ }^{9}$ possibilidades, expectativas e previsões conforme as partes vão se valendo, ou não, de suas chances durante o tramite processual. Esvazia-se o pretenso conteúdo de direitos e deveres entre as partes que dariam substancia a uma alegada relação jurídica. (GOLDSMITH, 1956, p. 8).

GOLDSMITH (1956, p. 5) ainda afirma que às partes cabe postular a prova e ao juiz prolatar a sentença. No que tange ao processo penal a atividade dos dois sujeitos, LOPES JÚNIOR (2012, p. 104-106) leciona que a atividade probatória ficaria limitada as partes, eis que a carga de fundamentar e provar o alegado na denúncia ou queixa-crime seria inteiramente do acusador. Dessa feita o imputado apenas teria as oportunidades de se defender. Ao magistrado, portanto seria vedada a atividade probatória. (LOPES JR., 2012, p. 104-106).

Sempre interessante trazer à tona a comparação que esta doutrina faz entre processo e guerra $^{10}$. Segundo os adeptos da presente corrente nos tempos de paz todos os direitos são certos. Contudo quando se dá início a uma guerra os direitos estão "na ponta da espada" e os direitos mais básicos se tornam incertos. (COUTURE, 1958, p. 136-137).

De forma semelhante ocorre no processo em que o fato do postulante ou do demandado serem de fato os titulares do direito não irá implicar necessariamente no seu reconhecimento. No processo é vencedor aquele que se vale de suas chances, se desincumbe de seus ônus. (CALAMANDREI, apud HARTMANN, 1951, p. 165). Em outros termos o reconhecimento do direito se dá em razão da prova produzida no processo. (GOLDSMITH, 1956, p. 8).

Ao trabalhar com estas premissas a doutrina em análise afasta a ingênua ideia de que aquele que tem a razão terá a certeza de sua vitória ao fim do processo. Isso conduz ao extermínio da "verdade real" no processo penal.

Várias são as críticas tecidas a esta teoria por processualistas como Franco CORDERO, Geovani $L E O N E^{11}$ dentro outros. Todavia, cingir-se-á a objeção que é levantada 
argumentando que a teoria em comento traria insegurança jurídica às decisões judiciais. De início não se pode afirmar que a teoria da situação jurídica foi a responsável por criar a insegurança jurídica, ao revés, esta apenas a desvelou. Sendo assim, com fulcro nas indispensáveis contribuições trazidas à tona é necessário se criar um discurso - e uma prática que dê racionalidade ao processo.

Daí que inexistindo a necessária correspondência entre assistir razão à parte e a procedência dos pedidos há de se buscar uma forma de se garantir alguma segurança aos cidadãos que estão sujeitos ao processo. A forma encontrada é pelo respeito às regras do jogo, em outros termos, pelo respeito às disposições legais e constitucionais que regem o processo penal.

Como é de se notar a presente teoria entende que a decisão judicial é legitimada pela estrita observância das regras processuais impostas. Tais regras, no ordenamento jurídico pátrio, podem ter natureza jurídica de princípios ou regra propriamente ditos. Estas normas, em muitas das vezes, constituem nos direitos fundamentais do imputado.

Robert ALEXY leciona que os direitos fundamentais adquirem a natureza de princípios, caracterizando, portanto, verdadeiros mandamentos de otimização. Nesta toada, é lícito concluir que o processo penal é o ambiente privilegiado para que o acusado exerça seu direito de resistir ao poder punitivo estatal.

Isto se dá por meio dos procedimentos que devem ser observados por parte do Estadojuiz para que ao final se prolate uma decisão, que poderá ser tanto absolutória quanto condenatória. Respeitar a forma de se produzir as provas, os requisitos para que se decretem prisões preventivas, o estado de inocência do acusado são condições essenciais para que haja segurança no processo penal. Condenações sumárias e processos midiáticos em nada contribuem para efetivas os valores de um Estado Democrático de Direito.

\footnotetext{
9 Tais ônus advém do próprio interesse em jogo no processo e não de qualquer relação com a parte $e x$ adversa.

${ }^{10}$ No antigo direito germânico o direito não era visto como uma forma de pacificação social, mas ao contrário era a guerra, a vingança. Dessa forma, em caso de homicídio cabia à família da vítima matar o ofensor. Todavia isso se dava de acordo com regras já estabelecidas. (FOUCAULT, 2002, p. 55-57).

${ }^{11}$ Para aprofundar o tema consultar a tese de Érica de Oliveira Hartmann que aborda de forma pormenorizada as críticas mais severas à teoria da situação jurídica.
} 


\section{DO PROCESSO PENAL COMO PROCEDIMENTO EM CONTRADITÓRIO}

Segundo lições de Aury LOPES JÚNIOR a teoria do processo como procedimento em contraditório, desenvolvida por Elio FAZZALARI, é uma continuação dos estudos de James GOLDSHMIDT. Isto se comprova pela utilização de conceitos desenvolvidos pelo processualista germânico, porém com nomenclatura diversa, tais como o dever e direito probatório - assemelhado com chances e descarga processual. (LOPES JR., 2012, p. 127).

Os autores que sustentam que o processo se caracteriza por um procedimento em contraditório têm como pressupostos as lições do administrativista italiano BEVENUTI (1952, p. 121-122). Conforme seus ensinamentos a função estatal nada mais é que a manifestação do poder da soberania em um ato. A função pode ser vista tanto pelo prisma subjetivo (administrativa, legislativa e judiciária) como também o prisma objetivo traduzido pelo movimento que dá concretude ao poder.

Desta sorte o poder estatal vai agir por meio de atos encadeados visando a um fim. Divide o procedimento em duas espécies. A primeira conhecida como procedimento em sentido estrito, na qual o órgão estatal age de forma unilateral com fito a satisfazer sua própria vontade. Noutro vértice o processo em que a vontade do órgão público é formada mediante o contraditório e a participação de vários sujeitos limitados pelos interesses dos destinatários do ato.

Pautado nestas lições Elio FAZZALARI (1958, p. 865) sustenta que o processo judicial é uma série da atos concatenados entre si, seguindo normas e princípios postos. Todavia afirma que para caracterização do processo judicial não basta apenas a participação de vários sujeitos na formação da vontade estatal. Ao contrário, faz-se mister que exista uma relação dialética marcada pelo efetivo contraditório.

A teoria em apreço tem o mérito de superar os defeitos traz idos pela teoria de Oskar Von BULLOW, eis que segundo esta o processo é um mero caminho até que o juiz prolate uma sentença. Desta feita, consagra-se a instrumentalidade das formas que enceta consequências diretas na teoria das nulidades. Uma vez alcançado o fim do ato, não há de se falar em nulidade. (LOPES JR., 2012, p. 128).

Em outro giro, o processo visto como procedimento em contraditório está a dar maiores poderes às partes, eis que a sentença só será legítima se for respeitado o contraditório, 
ou seja, a decisão estatal será formada com a devida participação das partes. O processualista italiano entende como contraditório o direito que as partes têm de serem informadas, bem como de participar em condições de paridade para a formação da decisão judicial.

Assim, a teoria de FAZZALARI tem o condão de redimensionar o papel do magistrado no processo penal. O juiz não é mais o contraditor das partes, não é mais dado a ele o papel de protagonista, ao revés assume a posição de garantidor do contraditório. Deve propiciar às partes o pleno debate e ao final prolatar sua decisão. Veja-se que desta feita não há mais espaço para o ativismo judicial em busca da "verdade real" ou "verdade alcançável". Não se pode tolerar prisões de ofício, inciativa probatória do magistrado dentre outros atos que engendram o desiquilíbrio processual. (LOPES JR., 2012, p. 129).

Sendo assim é salutar trazer à lume as lições de Érica de Oliveira HARTMANN (2010, p. 167) que assenta a importância do reconhecimento do contraditório em sede de processo penal para fins de dar ensejo a um processo penal democrático com a efetiva participação das partes.

No que concerne a previsão legal desta teoria há de se ressaltar que o Artigo $5^{\circ}$, inciso LV, da Constituição da República prevê expressamente que aos litigantes e acusados em processos judiciais e administrativos será assegurado o direito à ampla defesa e ao contraditório com todos os meios e recursos necessários para isto.

\section{INSTRUMENTALIDADE CONSTITUCIONAL DO PROCESSO PENAL}

Pois bem, após evidenciar que a atual Constituição de 1988 adota a teoria de Elio FAZZALARIA como natureza jurídica do processo, faz-se imprescindível para o presente ensaio perquirir se esta é suficiente para concretizar os ditames constitucionais em sede de persecução penal.

Para atingir este objetivo é imperioso abordar, mesmo que de forma perfunctória, a constitucionalização do direito brasileiro e a primazia dos direitos fundamentais. Pode-se afirmar que o marco zero deste processo foi a promulgação, em 1988, da Constituição Cidadã que trouxe em seu bojo respostas para o passado e futuro. Proibiu a tortura, previu valores 
como a erradicação da pobreza, a livre iniciativa, a valorização do trabalho e a dignidade da pessoa humana. (SCHIER, 2005, p. 1-7).

Todavia houve vozes que tentaram negar a força normativa da Carta Constitucional, havia também uma certa desconfiança acerca da efetivação das promessas constitucional, que se dava principalmente em razão da pouca efetividade de valores éticos e principiológicos na época da ditadura militar. (SCHIER, 2005, p. 1-7).

Desta sorte é preciso superar aquele velho Direito Constitucional, proveniente das revoluções burguesas, onde há o legicentrismo, relegando à Constituição a mera preocupação de organizar os Poderes e distribuir competência para se afirmar a posição central dos direitos fundamentais. (BONAVIDES, 2003, p. 384-387).

Para que isto ocorra torna-se imperioso que se tenha uma dogmática preocupada com a eficácia dos direitos fundamentais. Em outros termos, é preciso estabelecer uma interpretação do direito infraconstitucional que dê plena validade aos ditames constitucionais. Faz-se mister um sistema constitucional aberto às necessidades do tecido social, e que com ele entabule uma relação dialógica. (SCHIER, 1999, p. 91-100).

A ciência processual penal não poderia estar de fora deste processo. Deve-se ler toda a legislação pertinente à persecução criminal sob as lentes da Constituição Federal, dando efetividade às garantias do acusado.

Não é sem razão que Alexandre MORAIS DA ROSA e Júlio Cesar MARCELINO JÚNIOR conclamam a necessidade do reconhecimento da normatividade constitucional superando fatores existentes na realidade jurídica brasileira como a existência de teorias totalitárias como o Direito Penal do Inimigo, discurso de medo e recrudescimento penal, resistência ao modelo eminentemente acusatório preconizado pela Constituição da República; a existência de uma teoria geral do processo que não reconhece as idiossincrasias do Processo Penal e dificulta a implantação de valores constitucionais (NICOLITT, 2015, P. 47-50) a difusão de modelos coletivos de Segurança Pública dentre outros. (ROSA; MARCELINO JR., 2015 , p. 55-56).

Ademais, não se pode deslembrar que tanto o Código Penal quanto o Código de Procedimento Penal datam da década de 40, ocasião em que se vivenciava outro momento político, que era carente de valores democráticos. Desta sorte há de se buscar uma leitura 
constitucional destes diplomas legais e tantos outros que são até hoje promulgados com carência de densidade constitucional. (ROSA; MARCELINO JR., 2015, p. 55-56).

Nesse momento lícito asseverar que o processo penal é o meio necessário para que o Estado possa lançar mão do seu poder punitivo. Desta sorte, há de se respeitar em seu grau máximo de eficácia os direitos fundamentais do acusado. A legitimação da decisão judicial, em especial a condenatória, só pode se dar mediante a observação do procedimento e do contraditório. Em outras palavras, o processo penal é a seara privilegiada para que o imputado exerça seus direitos e garantias fundamentais em face do Estado repressor. (LOPES JR:, 2012, p. 88-90).

No que tange à eficácia dos Direitos Fundamentais de primeira dimensão na seara do processo penal, relembre-se SCHIER (2011, p. 1-2) que, apesar de referir-se ao direito administrativo, propugna pela aplicabilidade no objeto ora em estudo. Advoga a inexistência da supremacia do interesse público sobre o privado, eis que se trata de cláusula geral de restrição de direitos fundamentais sem força argumentativa suficiente para engendrar sua restrição.

Traçados os principais pontos acerca da instrumentalidade constitucional do processo penal, deve-se voltar à pergunta esboçada no início deste tópico, qual seja se a adoção da teoria de FAZZALARI é suficiente para garantir o respeito às garantias constitucionais do imputado em sede de persecução penal.

Neste sentido é imperioso concluir com Aury LOPES JÚNIOR em sentido negativo. Isto ocorre em virtude de que, embora a teoria de FAZZALARI garanta o contraditório, ela não traz em si todos os requisitos para engendrar um processo penal respeitador dos direitos fundamentais e que, por conseguinte, traga segurança jurídica. (LOPES JR., 2012, p. 131133).

Para que se dê ensejo à segurança jurídica no processo penal faz-se necessária a adoção conjunta da teoria de GOLDSCHMIDT e FAZZALARI entendendo-se que o processo consiste em um procedimento em contraditório respeitadas as regras do jogo. Todavia, não se trata de qualquer regra, está a se falar aqui de regras que observem os ditames constitucionais, ou seja, que tenham passado pelo imprescindível processo de filtragem constitucional. (LOPES JR., 2012, p. 131-133). 
Neste momento, tem-se fixado boa parte do arcabouço teórico necessário a discussão prática das consequências da adoção deste modelo teórico específico para o Processo Penal. A observância das regras - constitucionais - do jogo não permitirá a relativação de regras fundamentais para um processo penal democrático.

Exemplo que se tem é a recente decisão do Supremo Tribunal Federal em sede de Habeas Corpus 126.292 que permitiu o cumprimento provisório de pena após decisão de órgão colegiado sobre o caso penal. Neste momento o Poder Judiciário sucumbe aos clamores populares e, sob o pálio da ponderação, adota medida de eficiência na sanção estatal que, todavia, restringe de modo injustificado uma garantia fundamental de toda a sociedade.

Do mesmo modo que algumas conduções coercitivas e o vazamento de interceptações telefônicas, bem como prorrogações por diversas vezes destas conclui-se que não teriam espaço neste prisma teórico, eis que enfraquecem garantias de toda uma sociedade, exercidas de modo individual. Garantias como intimidade, presunção de inocência e liberdade tão caras a um sistema penal democrático.

\section{CONSIDERAÇÕES FINAIS}

O presente ensaio visou definir a natureza jurídica do processo penal e a partir de então traçar quais suas consequências no que diz respeito à segurança jurídica e aos direitos fundamentais.

Como se mostrou a teoria da relação jurídica é insuficiente para este fim, isto porque tem como pressuposto uma relação entre as partes consistente em deveres e obrigações mutuas. Também importa de forma equivocada alguns conteúdos do direito civil incompatíveis com o processo penal, o que ocasionou a formação de uma teoria das nulidades (que não consegue dar uma resposta satisfatória em sede de persecução penal).

A persecução criminal envolve interesses indisponíveis como a liberdade. Daí que é incabível se falar em instrumentalidade das formas e de nulidades relativas, eis que sempre que houver um desrespeito à forma haverá prejuízo para o imputado. No processo penal forma é garantia. 
De outra parte a teoria do processo como situação jurídica traz em seu bojo a epistemologia da incerteza, em outros termos, não se pode afirmar que o detentor do direito será o vencedor do processo, ou, em outros termos, que o acusado inocente será absolvido ao passo que o culpado será condenado.

Desta feita, há de se adotar aqui o respeito às regras processuais, a segurança jurídica se dá por meio da sua observância. Entretanto, não se fala aqui na observância de qualquer regra, mas de regras em conformidade com a Constituição Federal, e, principalmente, com a eficácia dos direitos fundamentais.

Imperioso ressaltar que não se admite a existência de direitos fundamentais absolutos, eis que todos podem ser restringidos, o que se exige é a correta fundamentação para sua restrição. Ademais, é preciso superar a errônea ideia de que o respeito aos direitos fundamentais dá causa à impunidade.

Por fim, evidenciou-se a importância da teoria de FAZZALARI, pois esta privilegia o contraditório efetivo nos processos, dando margem a um processo penal democrático.

\section{DOCUMENTOS CONSULTADOS}

BEVENUTI, Feliciano. Funzione aamministrativa, procedimento, processo. Rivista trimestrale di diritto pubblico, Milno, Giufrê, a. II, n.11. 1952.

BONAVIDES, Paulo. Curso de Direito Constitucional. 13 ed. São Paulo: Malheiros, 2003. BULLOW, Oskar von. Las Excepciones y los pressupuestos procesales. Peru: Instituto Pacífico, 2015.

CALAMANDREI, Piero. Um maestro de liberalismo processuale. Rivista di diritto processuale. Padova: Cedam. v. VI. n. 1. 1951.

CINTRA, Antonio Carlos de Araújo; GRINOVER, Ada Pellegrini; DINAMARCO, Cândido Rangel. Teoria Geral do Processo. 11 ed. São Paulo: Malheiros, 2005. 
CAMARGO, Acir Bueno. Windscheid e o rompimento com a fórmula de Celso. in.: COUTINHO. Jacinto Nelson de Miranda. Crítica à Teoria Geral do Processo Penal. Rio de Janeiro: Renovar, 2001.

COUTURE, Eduardo. Fundamentos de Drechoprocesal civil. Buenos Aires: Depalma, 1958.

FAZZALARI, ELIO. Difusione del processo e compitti della dotrinna Rivista trimestrale di diritto e procedura civile. a. XII. v. 2., 1958.

FOUCAULT, Michel. A verdade e as formas jurídicas. 3 ed. Rio de Janeiro: Nau , 2002. GOLDSCHMIDT, James. DerechoProcesal Civil. Barcelona: Labor, 1956.

HARTMAnn, Érica de Oliveira. Processo Penal e Rito Democrático: a simplificação dos procedimentos como condição de possibilidade de contraditório e ampla defesa. 2010. 330f. Tese (Doutorado em Direito) Setor de Ciencias Jurídicas. Universidade Federal do Paraná.

LOPES JÚNIOR, Aury. Direito Processual Penal. 9 ed. São Paulo: Saraiva, 2012. MARQUES, Allana Campos. A relação jurídica processual como retórica: uma crítica a partir de James Golscbhmidt. In: COUTINHO, Jacinto Nelson de Miranda. Crítica à teoria geral do processo penal. Rio de Janeiro: Renovar, 2001.

MANSINI, Vincenzo. Tratado de derecho procesal penal. tomo I, Buenos Aires: El Foro, 1951.

MARQUES, Frederico. O Júri e sua nova regulamentação legal. São Paulo: Saraiva, 1948. MORAIS DA ROSA, Alexandre; MARCELINO JÚNIOR, João Cesar. O processo eficiente na lógica econômica: desenvolvimento, aceleração e direitos fundamentais. Florianópolis: Empório do Direito, 2015.

NICOLITT, André. Manual de Processo Penal. 5 ed. rev. Atal e ampl. São Paulo: Revista dos Tribunais, 2015.

SCHIER, Paulo Ricardo. Novos Desafios da Filtragem Constitucional no Momento do Neoconstitucionalismo. In Revista Eletrônica de Direito do Estado. Salvador: n. 4. Out/Dez 2005. 
SCHIER, Paulo Ricardo. Ensaios sobre a supremacia do interesse público sobre o privado e o regime jurídico dos Direitos Fundamentais. In: Revista Eletrônica de Direito Administrativo Econômico. n 26. Maio/julho de 2011.

TORNAGHI, Hélio. Compendio de Processo Penal. Tomo I. Rio de Janeiro: José Konfino, 1967. 